\title{
How to Build Pride in the Workplace?
}

\author{
Leandro Pereira ${ }^{1,2, *}$, Vânia Patrício ${ }^{2}$, Mariana Sempiterno ${ }^{2}$, Renato Lopes da Costa ${ }^{1} \oplus$, Álvaro Dias ${ }^{1,3}$ \\ and Nélson António ${ }^{1}$ \\ 1 Business Research Unit, ISCTE Business School, 1649-026 Lisbon, Portugal; \\ renato_jorge_costa@iscte-iul.pt (R.L.d.C.); alvaro.dias@iscte-iul.pt (Á.D.); nelson.antonio@iscte-iul.pt (N.A.) \\ 2 Winning Lab, 1750-149 Lisbon, Portugal; vania.patricio@winning.pt (V.P.); \\ mariana.leite.sempiterno@winning.pt (M.S.) \\ 3 School of Economic and Organizational Sciences, Universidade Lusófona de Humanidades e Tecnologias, \\ 1749-024 Lisbon, Portugal \\ * Correspondence: leandro.pereira@iscte-iul.pt
}

Citation: Pereira, Leandro, Vânia Patrício, Mariana Sempiterno, Renato Lopes da Costa, Álvaro Dias, and Nélson António. 2021. How to Build Pride in the Workplace? Social Sciences 10: 104. https://doi.org/ 10.3390/socsci10030104

Academic Editor: Nigel Parton

Received: 8 February 2021

Accepted: 15 March 2021

Published: 19 March 2021

Publisher's Note: MDPI stays neutral with regard to jurisdictional claims in published maps and institutional affiliations.

Copyright: (c) 2021 by the authors. Licensee MDPI, Basel, Switzerland. This article is an open access article distributed under the terms and conditions of the Creative Commons Attribution (CC BY) license (https:// creativecommons.org/licenses/by/ $4.0 /)$.

\begin{abstract}
Organizational pride has been proved to benefit organizations by enhancing commitment and reducing turnover cost, encouraging employees to go a step further and consequently increase production and improve performance. Despite the fact that its effects on organizations have been studied, it is still not clear how can organizational pride be created. The aim of this research is to identify the drivers of organizational pride and define strategies that help organizations develop it. Its main contribution is that it performs a comprehensive study on the causes of organizational pride, not focusing only on one or two contributors and not considering organizational pride as an intermediary but as a goal. Using a partial least square path model it was possible to conclude that organizations need to make employees feel appreciated by involving them in the decision making process, and promote the organization's values so employees can relate to them and maintain honest communications to enhance management credibility.
\end{abstract}

Keywords: organizational pride; pride experience; work engagement

\section{Introduction}

The new global competitive environment draws out the importance of organizations being able to attract and maintain talented employees. Foresight leaders want to understand what matters the most to employees in order to distinguish themselves from competition (Holtom et al. 2019). Although financial incentives and monetary rewards are still relevant, they are no longer the main attraction factors for talented employees (Arshad and Imran 2016). Organizational values and morality, for instance, can shape the way workers view their jobs and make them go above and beyond the call of duty. Employee engagement and higher performance levels can both be set off by organizational pride (Katzenbach 2003).

Organizations need to know how they can build organizational pride, since this sentiment can nurture an emotional commitment that monetary compensation does not. They need to understand what makes their employees proud of the organization and of the role they play, so they can define strategies to enhance this feeling. Organizational pride will not only reduce turnover intentions by encouraging commitment but it can also reduce stress among employees and improve team support (Durrah et al. 2019).

The key question this study aims to answer is how can organizations build up pride in the workplace. The goal is to find what makes employees identify with their organizations and be proud to be a part of that structure. Once these triggers are identified, particular approaches can be defined to promote organizational pride.

The main contribution of this study is the development of a comprehensive study of organizational pride. The next section presents an overview of the research made on 
organizational pride, its causes and relevance. In order to study the triggers of organizational pride, a survey was conducted on 80 employees from a management consulting firm. The approach and results from this survey are described in Research Methodology and Data Analysis, respectively. The following section compares the results to the literature's findings and identifies specific measures that can be implemented in organizations. The final chapters include conclusions, limitations and guidance for future research.

\section{Literature Review}

There has been a lot of research on what makes an organization a great place to work (GPTW). At first, these lists were regarded just as publicity methods for ranked firms; however, researchers have found a significant link between firms awarded with GPTW certification and company performance (Butler et al. 2016). These organizations are often described as reliable employers, and places where employees take pride in their work and like the people they work with.

In the current competitive world where lifetime employment is no longer the norm, job satisfaction and organizational engagement or commitment play an important role. Nevertheless, the research on organizational engagement is not new (Buchanan 1974). Schaufeli et al. (2006) define work engagement as the opposite of work burnout and as a rewarding work-related feeling portrayed by drive, devotion and immersion. Nevertheless, the authors were solely focused on measuring work engagement. Ellemers et al. (2011) found that organizational pride can elicit not only satisfaction with the job but also commitment to the organization. Furthermore, the authors found evidence that pride can be a better motivator of positive behavior than monetary incentives. Supporting this, organizational pride was also found to be a powerful driver of performance (Butler et al. 2016). More recently, organizational pride was positively related with reducing turnover and becoming a strategic asset to differentiate organizations (Durrah et al. 2019).

Pride is primarily an emotion related to ones' performance that is usually associated with a personal success or achievement (Arnett et al. 2002; Tracy and Robins 2007). Gouthier and Rhein (2011) divide organizational pride into two components: affective pride, a temporary emotion sustained by a successful event related to the organization; and cognitive pride, a durable emotion caused by the general opinion of the organization. Helm (2013) defines organizational pride as "the pleasure taken in being associated with one's employer" (p. 544), the sense of pleasure of being a member of the organization. Masterson et al. (2017) confirmed that organizational pride is a separate emotion, which employees experience when they find that their organization creates value and makes a difference, that makes them want to endorse it to others. For the purpose of this study, organizational pride will focus on Helm (2013) and Masterson et al. (2017) definition - the feeling of pleasure associated with being part of the organization that makes employees want to endorse it to others.

Organizational pride was initially linked with job satisfaction, either because it could drive from the satisfaction of employees with their employer or because they were usually studied in parallel, reporting similar causes or consequences (Arnett et al. 2002; De Roeck et al. 2016; Doh et al. 2011; Durrah et al. 2019; Holtom et al. 2008). Both concepts were proven to increase commitment to the organization and reduce turnover intentions (Brosi et al. 2018; Holtom et al. 2019; Lehtman and Zeigler-Hill 2020; Ng et al. 2019). Although some authors propose the opposite relationship, considering organizational pride a consequence of organizational engagement (Farooq and Salam 2020; Nakamura 2013), this paper focus on the most consensual model proposing

Hypothesis 1 (H1). Organizational Pride positively effects Organizational Commitment.

Furthermore, following Allen and Meyes (1990) study, this paper opted to distinguish between odrganizational commitment-the meaning that workers attribute to their work and make them want to go the extra mile, and affective commitment-the feeling of belong- 
ing to a "family" and caring about each other. Masterson et al. (2017) had also concluded that affective commitment, though related to organizational pride, is a distinct construct.

Hypothesis 2 (H2). Affective commitment is positively associated with Organizational Commitment (a) and Organizational Pride (b).

Although the idea that how much a person identifies with its own organization is widely accepted as contributing to the feeling of pride and commitment (Durrah et al. 2019; Gouthier and Rhein 2011; Lu and Roto 2016; Masterson et al. 2017; Muzakki 2020; Welander et al.2017), the concept of identification can be divided into two types. De Roeck et al. (2016) distinguished situational identification-the idea of being a member of a group, that can be achieved rapidly but it is essentially a temporary feeling, from organizational identification. Organizational identification is a separate construct that portrays a deeper identification that comes from one relating to the core believes of an organization.

Hypothesis 3 (H3). Organizational Identification positively effects Organizational Commitment (a), Affective Commitment (b) and Organizational Pride (c).

Organizational pride has been studied in several different contexts: the hospitality sector (Arnett et al. 2002; Fiernaningsih et al. 2019; Hameed et al. 2019; Kashif et al. 2017; Raza et al. 2021), multiple services focused on costumer contact (Gouthier and Rhein 2011; Kraemer et al. 2020; Ng et al. 2019), volunteers (Boezeman and Ellemers 2014), creativity intense contexts, such as advertising or engineering (Arshad and Imran 2016; Lu and Roto 2016), industrial contexts (Durrah et al. 2019; Seyedpour et al. 2020), and educational environments (Brosi et al. 2018; Widyanti et al. 2020), among others. However, most authors study organizational pride as a mediator between some organizational characteristics and performance, commitment or turnover reduction. With the exception of Seyedpour et al. (2020), who have researched what creates organizational pride in the National Iranian Oil Company (NIOC), most researches focus on very segmented causes or consequences of organizational pride.

Arnett et al. (2002) found that role clarity, work environment and employees' assessment of manager's performance critically impacts job satisfaction. Leader influence and management support was also linked to reduced turnover (Holtom et al. 2008), increased job satisfaction and promoting the feeling of pride (Doh et al. 2011). Welander et al. (2017) added that besides management support, co-worker support and work conditions influence the feeling of organizational pride mediated by organizational identification.

Hypothesis 4 (H4). Work conditions positively effects Organizational Identification (a) and Organizational Pride (b).

Hypothesis 5 (H5). Management support positively effects Organizational Identification (a) and Organizational Pride (b).

Hypothesis 6 (H6). Co-worker support positively effects Organizational Identification (a) and Organizational Pride (b).

Effective support is usually based on meaningful relationships and it cannot be dissociated from affection (Holtom et al. 2008).

Hypothesis 7 (H7). Co-worker (a) and management (b) support are positively related to Affective Commitment.

Ellemers et al. (2011) identified the morality of an organization as an important characteristic that leads to organizational pride and identification.

Hypothesis 8 (H8). Organizational morality positively effects Organizational Identity (a) and Organizational Pride (b).

Moreover, De Roeck et al. (2016) found that justice perceptions also influenced job satisfaction and organizational pride. Procedural aspects, regarding the objectivity of procedures in place and ability of one to have a voice in them is also corroborated by 
Katzenbach (2003). The attribution of rewards based on performance and personal achievement and not on biases and personal preferences from the manager, also known as distributive justice, is widely accepted as having an impact on job satisfaction, organizational identification and pride (Doh et al. 2011; Masterson et al. 2017). The clarity of communications defined by informational justice is also supported by Lu and Roto (2016).

Hypothesis 9 (H9). Procedural Justice (a), Distributive Justice (b) and Informational Justice (c) have a positive effect on Organizational Pride.

Since the morality of an organization is highly dependent of justice perceptions, this study also takes this interaction into account.

Hypothesis 10 (H10). Procedural Justice (a), Distributive Justice (b) and Informational Justice (c) have a positive effect on Moral.

The importance of a proper work-life balance as a source of job satisfaction and organizational pride has been identified by Mas-Machuca et al. (2016). Employees need to feel that they are able to live their personal lives in order to be able to feel proud of their organizations (Fiernaningsih et al. 2019).

Hypothesis 11 (H11). Work-life balance is positively associated with Organizational Pride.

More recently, there has been a high interest in studying the effects of corporate social responsibility on organizational pride. As previously found by Helm (2013), external perceptions are very relevant for the feeling of pride, as well as the idea of one's own organization making a difference. The contributions of organizations towards helping and protecting the society and environment are seen as a source of pride for all employees (Farooq and Salam 2020; Hameed et al. 2019; Muzakki 2020; Raza et al. 2021).

Overall, organizational pride has been widely accepted as an important driver of performance and that reduces turnover costs. However, most approaches to the subject are segmented. Organizational pride should be analyzed as a consequence of the intricate dependencies of the organization as a whole.

\section{Research Methodology}

In order to understand what makes employees proud of their organization, a survey was conducted in a management consulting firm. The survey consisted in 81 questions ranked from 1 to 5 in a Likert scale that assessed how important or frequent something was or the extent of agreement with a statement. From the 145 surveys delivered, it was possible to use 80 that were completely filled out.

When considering complex concepts representing feelings, sensations or perceptions, structural equation modeling (SEM) is a better solution, allowing one to define "constructs" through multiple indicators, estimate models with more than one dependent variable and study the relationship between concepts (Gefen et al. 2011). Due to its ability to model complex structures between theoretical concepts, SEM has become a valuable statistical technique in behavioral and social sciences (Benitez et al. 2020). To model the complex relationships between different aspects of the organization gathered by different questions, a partial least squares (PLS) path model was used. PLS path modeling is a SEM technique based on variance. The PLS was the SEM modeling technique chosen because the main goal was to perform exploratory research through latent constructs; the sample was small and not normally distributed (Farooq and Salam 2020; Hair et al. 2016). All analysis was performed with Python, using the "plspm" package, a port of the $\mathrm{R}$ package "plspm" developed by Gaston Sanchez, with additional features adopted from the R package "seminr".

\section{Results}

The survey was answered by 80 people: out of these, $58 \%$ were male, $54 \%$ were between 26 and 40 years old and $65 \%$ had worked in the company for more than a year. 


\section{PLS Path Model}

The 81 questions were used to characterize the sample, build the concepts needed (indicators) and to validate the data, eliminating answers that were contradictory or not consistent. For each concept, a set of indicators were selected from the literature that were later on reduced based on the results obtained. Pride was defined by six indicators such as "I am proud to say that I work for this organization" (Arredondo Trapero et al. 2017; Welander et al. 2017) or "I feel that my contribution is making a difference in the organization" (Masterson et al. 2017). Commitment was measured with five indicators that asked about willingness to go to work, how long a person wants to keep working for the organization or about the meaning of the job done (Allen and Meyes 1990; Kraemer et al. 2020; Schaufeli et al. 2006). Work condition is a more broad concept that included six indicators, for instance, "My function is adequate to my competences and abilities" or, "My work provides challenging and interesting tasks" (Cable and Turban 2003). Affective commitment was measured by four indicators concerning the relationships inside the organization and the feeling of belonging (Allen and Meyes 1990). Work-life balance was defined according to Fiernaningsih et al. (2019) by measuring the schedule flexibility or policies that the organization might have to promote this balance. Justice's nine indicators were divided into three components: procedural, assessing if the employees have a say in the organization policies that affect them; distributive, related to rewarding policies and their transparency; and informative, the quality and effectiveness of communications in the organization (Ambrose and Schminke 2009). The ethics and honesty of the organization was assessed in "moral", with three indicators as suggested by Ellemers et al. (2011). Identification with the organization and co-worker support was simply measured by one indicator each, by asking if the employee identifies with the organization and if they can rely on their colleagues if needed (Welander et al. 2017). Finally, management support was first measured according to Welander et al. (2017) with a total of fourteen indicators.

These indicators and concepts were used to estimate a PLS path model. The first step was to verify the quality of the measurement models used. The constructs were all measured through reflective indicators because the constructs are either a trait explaining the indicators, there is a causal relationship from construct to indicators or the indicators represent consequences of the construct (Hair et al. 2016). According to recommendations of Hair et al. (2016), all indicators with loadings smaller than 0.7 were eliminated; the next step was to evaluate the cross-loadings to verify if the indicators are correctly associated with the constructs. All indicators which obtained their higher loadings for other constructs than those that were measured were eliminated. Then, all indicators which had the second highest loading very close to the highest were also eliminated to guarantee discriminant validity. Furthermore, all concepts had their internal consistency reliability checked (Cronbach's $\alpha>0.7$ ) and their convergence validated (AVE (average variance extracted) > 0.5). At this point, most constructs were measured by four indicators maximum, except management support. Even though confirmatory factor analysis only indicated one factor among these indicators (only one eigen-value higher than 1), their definitions pointed to three different concepts. When the construct was divided not only was it possible to barely reduce the Cronbach's $\alpha$ (that is sensitive to the number of indicators (Hair et al. 2016)), but also improve the convergent and discriminant validity of the indicators used and goodness of fit of the model to 0.75 . Therefore, the management support was divided into management competence (trying to approximate the idea of competence presented by (Lu and Roto (2016)), appreciation, that assesses how much the organization and/or management superiors value employees' input and recognize their efforts, and finally, management support only included the relationship with subordinates.

The model obtained a goodness of fit of 0.75 . All weights and loadings of the final set of indicators (Table 1) are significant at 0.01 , and all concepts have a Dillon Goldstein $\rho$ higher than 0.857 . 
Table 1. Indicators and latent variables.

\begin{tabular}{|c|c|c|c|c|c|}
\hline Code & Indicator & Cronbach's $\alpha$ & AVE & Weight & Loading \\
\hline & Affective Commitment & 0.885 & 0.809 & & \\
\hline $\mathrm{AC} 1$ & \multicolumn{3}{|c|}{ We care about each other. } & 0.282 & 0.852 \\
\hline AC2 & \multicolumn{3}{|c|}{ There is a team/family spirit within the company. } & 0.402 & 0.926 \\
\hline AC3 & \multicolumn{3}{|c|}{ We are all on the same boat. } & 0.387 & 0.919 \\
\hline & Appreciation & 0.874 & 0.796 & & \\
\hline AP1 & \multicolumn{3}{|c|}{ Management recognizes work well done and extra work } & 0.400 & 0.932 \\
\hline AP2 & \multicolumn{3}{|c|}{ Everyone has the chance to be recognized. } & 0.364 & 0.879 \\
\hline AP3 & \multicolumn{3}{|c|}{ Management genuinely listens to ours suggestions and addresses them. } & 0.302 & 0.845 \\
\hline & Commitment & 0.818 & 0.731 & & \\
\hline $\mathrm{C} 1$ & \multicolumn{3}{|c|}{ My work has a special meaning, it is not just a job. } & 0.421 & 0.893 \\
\hline $\mathrm{C} 2$ & \multicolumn{3}{|c|}{ I look forward to come to work. } & 0.355 & 0.844 \\
\hline $\mathrm{C} 3$ & \multicolumn{3}{|c|}{ I feel motivated to go beyond my formal responsibilities. } & 0.379 & 0.828 \\
\hline
\end{tabular}

Co-worker Support-We can count on

our colleagues cooperation.

Identification-I identify with the company's brand.

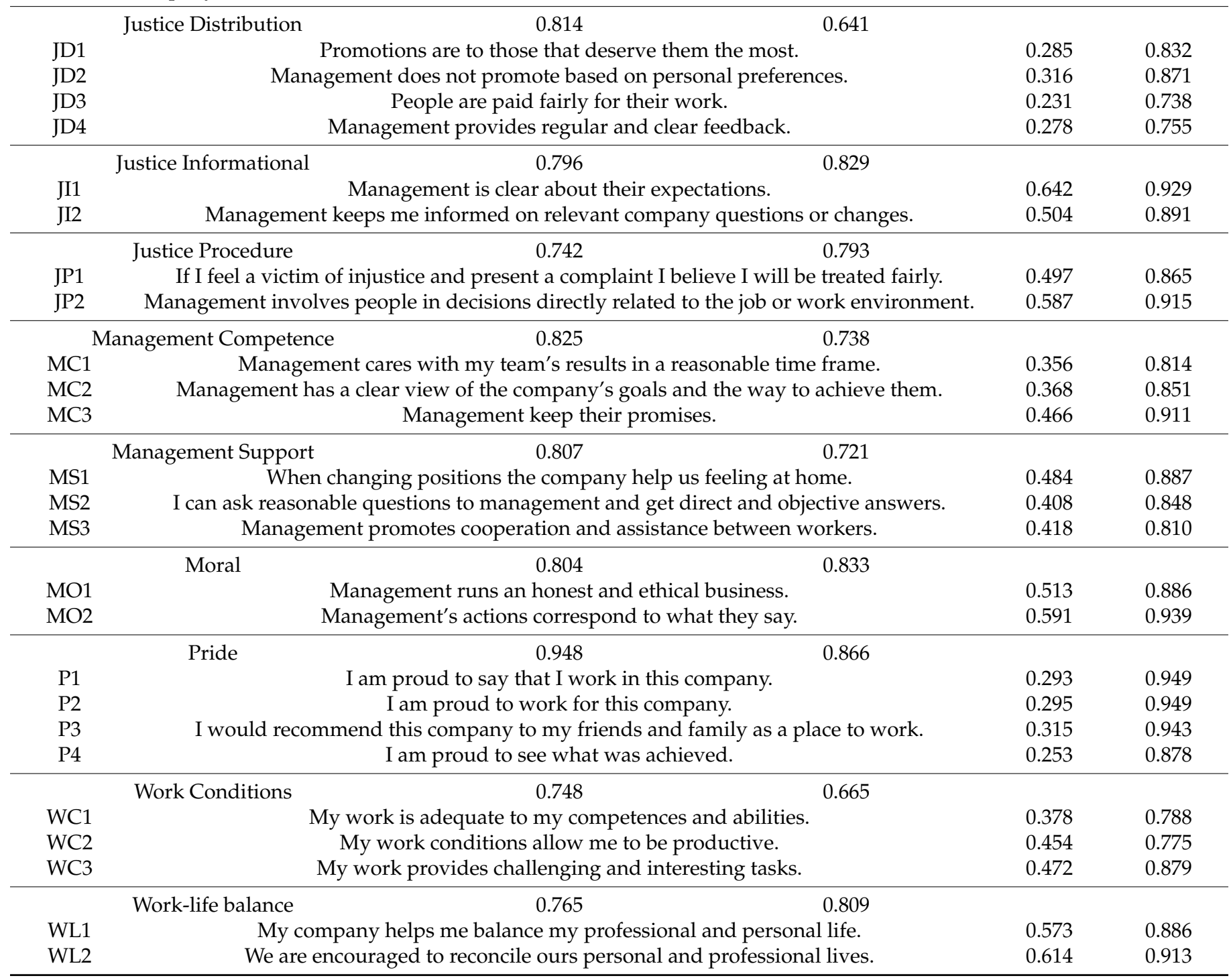


In order to better understand the role of each construct analyzed, the total effects of the hypothesized relationships are presented in Table 2, along with direct and indirect effects, while Figure 1 shows all significant relationships. As expected, organizational pride and affective commitment are effective mediators of organizational identification (and respective underlying related constructs) and commitment. Organizational identification is also a powerful mediator between management support, work conditions and organizational pride.

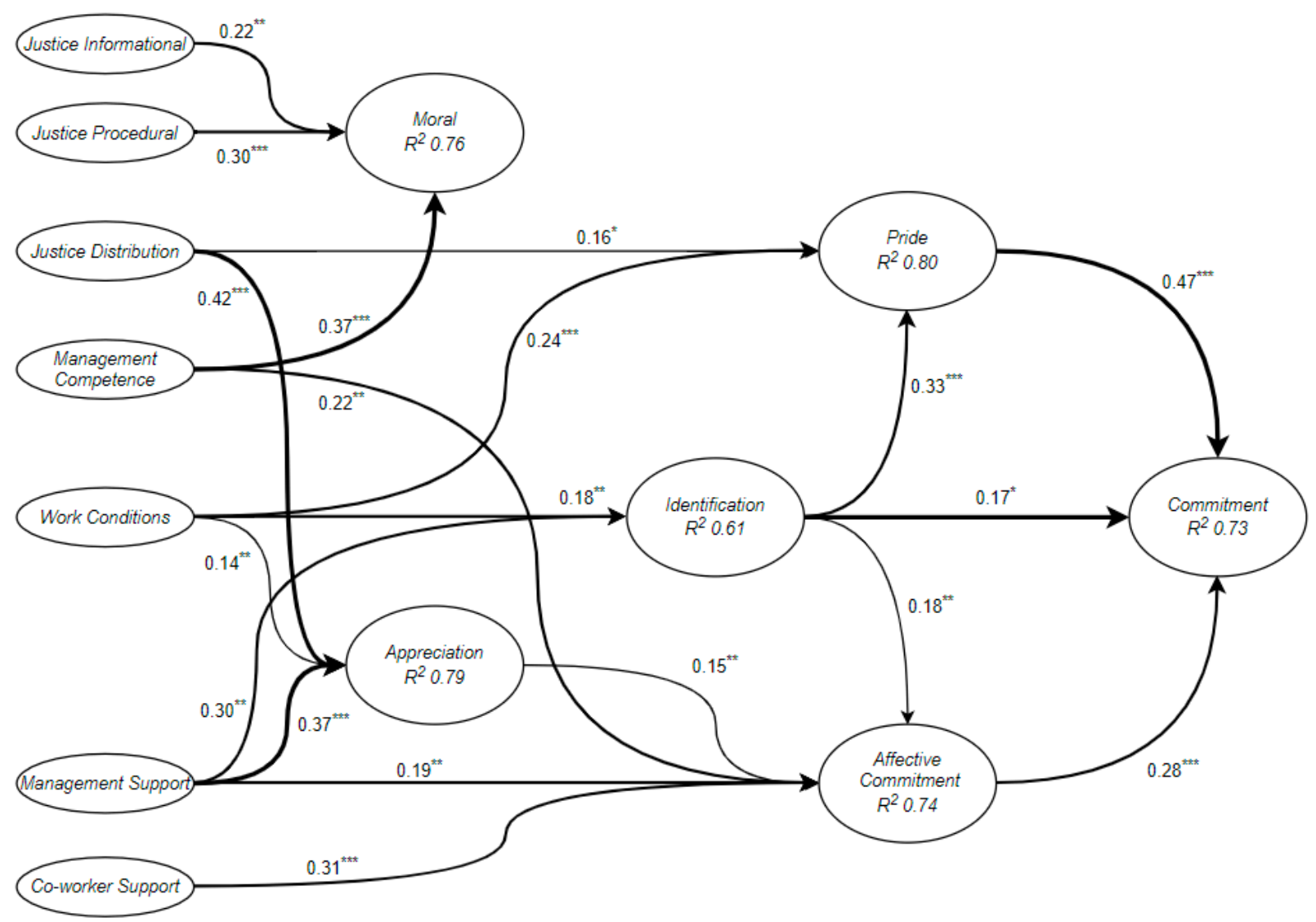

Figure 1. Partial least squares (PLS) model. All the significant relationships ( ${ }^{* * *}$ significant at $0.01,{ }^{* *}$ significant at 0.05 , * significant at 0.1 ) are described in Figure 1, where the weights of the arrows correspond to the magnitude of the effect (weak, medium or large). The $\mathrm{R}^{2}$ of the different concepts correspond to the amount of variance that was explained by the related concepts in the model. The PLS path modeling achieved not only a significant goodness of fit but also a model that explains most of pride's variance $\left(R^{2}=0.80\right)$.

Table 2. Direct and indirect effects.

\begin{tabular}{ccccc}
\hline From & To & Direct & Indirect & Total \\
\hline Pride & Commitment & $0.47^{* * *}$ & & $0.47^{* * *}$ \\
Affective Commitment & Commitment & $0.28^{* * *}$ & $0.007^{\mathrm{NS}}$ & $0.29^{* * *}$ \\
Identification & Pride & $0.33^{* * *}$ & $0.002^{\mathrm{NS}}$ & $0.33^{* * *}$ \\
Identification & Affective Commitment & $0.18^{*}$ & & $0.18^{*}$ \\
Identification & Commitment & $0.17^{*}$ & $0.20^{* *}$ & $0.37^{* *}$ \\
Co-worker Support & Pride & $-0.04^{\mathrm{NS}}$ & $0.05^{\mathrm{NS}}$ & $0.01^{\mathrm{NS}}$ \\
Co-worker Support & Identification & $0.12^{\mathrm{NS}}$ & $0.01^{\mathrm{NS}}$ & $0.13^{\mathrm{NS}}$ \\
Co-worker Support & Affective Commitment & $0.31^{* * *}$ & $0.01^{\mathrm{NS}}$ & $0.32^{* * *}$ \\
Management Support & Pride & $0.09^{\mathrm{NS}}$ & $0.09^{* *}$ & $0.18^{*}$ \\
Management Support & Identification & $0.30^{*}$ & $-0.05^{\mathrm{NS}}$ & $0.25^{*}$ \\
Management Support & Appreciation & $0.37^{* * *}$ & & $0.37^{* * *}$ \\
Management Support & Affective Commitment & $0.19^{* *}$ & $0.09^{*}$ & $0.28^{* * *}$ \\
\hline
\end{tabular}


Table 2. Cont.

\begin{tabular}{ccccc}
\hline From & To & Direct & Indirect & Total \\
\hline Appreciation & Pride & $0.02^{\mathrm{NS}}$ & $-0.04^{\mathrm{NS}}$ & $-0.02^{\mathrm{NS}}$ \\
Appreciation & Affective Commitment & $0.15^{*}$ & $-0.02^{\mathrm{NS}}$ & $0.12^{*}$ \\
Work Conditions & Pride & $0.24^{* * *}$ & $0.05^{* *}$ & $0.29^{* * *}$ \\
Work Conditions & Identification & $0.18^{*}$ & $-0.02^{\mathrm{NS}}$ & $0.16^{*}$ \\
Work Conditions & Appreciation & $0.14^{* *}$ & & $0.14^{* *}$ \\
Management Competence & Moral & $0.37^{* * *}$ & & $0.37^{* * *}$ \\
Management Competence & Pride & $0.08^{*}$ & $0.10^{\mathrm{NS}}$ & $0.18^{*}$ \\
Management Competence & Identification & $0.25^{\mathrm{NS}}$ & $-0.03^{\mathrm{NS}}$ & $0.22^{\mathrm{NS}}$ \\
Management Competence & Affective Commitment & $0.22^{* * *}$ & $0.05^{*}$ & $0.27^{* * *}$ \\
Justice Distribution & Pride & $0.16^{*}$ & $0.03^{\mathrm{NS}}$ & $0.19^{*}$ \\
Justice Distribution & Appreciation & $0.42^{* * *}$ & & $0.42^{* * *}$ \\
Justice Distribution & Moral & $0.08^{\mathrm{NS}}$ & & $0.08^{\mathrm{NS}}$ \\
Justice Procedural & Pride & $0.17^{\mathrm{NS}}$ & $0.05^{\mathrm{NS}}$ & $0.23^{\mathrm{NS}}$ \\
Justice Procedural & Moral & $0.30^{* * *}$ & & $0.30^{* * *}$ \\
Justice Informational & Pride & $-0.16^{\mathrm{NS}}$ & $-0.01^{\mathrm{NS}}$ & $-0.17^{\mathrm{NS}}$ \\
Justice Informational & Moral & $0.22^{* *}$ & & $0.22^{* *}$ \\
Moral & Identification & $-0.04^{\mathrm{NS}}$ & & $-0.04^{\mathrm{NS}}$ \\
Moral & Pride & $0.07^{\mathrm{NS}}$ & $-0.01^{\mathrm{NS}}$ & $0.06^{\mathrm{NS}}$ \\
Work-life Balance & Pride & $0.02^{\mathrm{NS}}$ & $0.04^{\mathrm{NS}}$ & $0.06^{\mathrm{NS}}$ \\
\hline
\end{tabular}

*** significant at $0.01,{ }^{* *}$ significant at $0.05,{ }^{*}$ significant at $0.1,{ }^{\mathrm{NS}}$ not significant.

\section{Discussion}

The PLS path modeling identified some strong and significant relationships with organizational pride. Contradicting the models proposed by Farooq and Salam (2020) and Nakamura (2013), and supporting the most general belief, it was possible to validate H1, finding that organizational pride has a strong positive effect on organizational commitment.

Although Masterson et al. (2017) found that affective commitment is related to organizational pride, this study was only able to find support to validate $\mathrm{H} 2(\mathrm{a})$, linking affective commitment to organizational commitment. Organizational identification was found to be a powerful mediator to organizational pride. In addition, although it was possible to find evidence that supports $\mathrm{H} 3(\mathrm{a})$, (b) and (c), the effect of organizational identification is stronger on organizational pride, which indirectly increases the effect on organizational commitment, supporting most previous studies (Durrah et al. 2019; Gouthier and Rhein 2011; Lu and Roto 2016; Masterson et al. 2017; Muzakki 2020; Welander et al. 2017).

Work conditions was found to be the second main promotor of organizational pride, supporting the findings of Arnett et al. (2002) and Welander et al. (2017). It not only directly caused organizational pride but also indirectly through organizational identification, which confirmed H4(a) and (b). Furthermore, due to the decomposition of management support in three different constructs, it was possible to discover that good work conditions also influence the feeling of appreciation, helping employees feel valuable to the organization.

Management support was divided into three components, and it can be seen that although appreciation is supported by the relationship with management and superiors characterized in management support, there is no relationship between these two constructs and management competence. These results support the choice to deconstruct the original concept of management support in order to better understand its relevance to organizational pride. The model shows that management support and appreciation have a positive effect on affective commitment, supporting H7(b). Although appreciation has no effect on organizational pride, management support has a positive indirect effect through organizational identification, supporting H5(a) and partially H5(b). Management competence was also found to be related to affective commitment, but even more with the moral of the organization. It can be concluded that the relationship between employees and management, the perception of management competence and the feeling of being a valued member towards the organization influence organizational commitment through 
affective commitment but not organizational pride directly. Regarding co-worker support, it was only possible to confirm its positive effects on affective commitment, validating H7(a), but there was no evidence to support H6(a) not (b). Although not confirming Welander et al. (2017) position on management and co-worker influence, these conclusions do not contradict the idea that management support not only promotes job satisfaction but also reduces turnover (Arnett et al. 2002; Holtom et al. 2008).

Although the morality of an organization appears to be highly related to one's ability to identify with it (De Roeck et al. 2016), and Ellemers et al. (2011) pointing it out as one of the main reasons for the creation of organizational pride, it was not possible to find evidence supporting H8(a) nor (b). Regarding the different types of justice included in the model, it was possible to relate them all to the morality of the organization, supporting H10(a), (b) and (c). On the other hand, only distributive justice was found to influence organizational pride, validating $\mathrm{H} 9(\mathrm{~b})$, but not $\mathrm{H} 9(\mathrm{a})$, nor $\mathrm{H} 9$ (c). Although some authors found that clear communication, objective procedures and a voice to influence such procedures was important to promote organizational pride, it was not possible to confirm their results (Katzenbach 2003; Lu and Roto 2016). However, not only was it possible to relate the objectivity of the rewarding processes to organizational pride, but also with appreciation, making a link with Katzenbach (2003) position on the importance of rewards and the celebration of small achievements.

Finally, it was not possible to significantly relate work-life balance with any other construct of the model, not supporting H11. Despite the relevance of this concept for pharmaceutical companies or in the hospitality business (Fiernaningsih et al. 2019; MasMachuca et al. 2016), the inquired sample did not seem to find it as important.

The main contribution of this paper is that it elucidates what positively effects organizational pride, instead of looking at organizational pride as a means to reduce turnover (Doh et al. 2011; Helm 2013; Holtom et al. 2019), increase engagement (Buchanan 1974), increase productivity (Arshad and Imran 2016; Butler et al. 2016) or to improve employee behavior (Brosi et al. 2018; Gouthier and Rhein 2011; Kraemer et al. 2020). Welander et al. (2017) and Seyedpour et al. (2020) used confirmatory factor analysis and structural equation modeling to understand the relationship between organizational pride and its drivers, building more comprehensive models than most of the other authors. Nevertheless, the first only considers perceived co-worker support, perceived supervisor support, satisfaction with work conditions and job autonomy as independent concepts and the later intrinsic motivation, national pride, organizational image, successful background of organization and importance of organization's output. Both models lack some of the concepts that were identified in this paper as the most relevant. Neither mentions distributive justice or some kind of rewarding practices or distinguishes between effecting pride or affective commitment. Furthermore, while the first includes the support provided by managers even if ignoring its different aspects (appreciation or competence), the second ignores the management role all together.

An organization's strategy to build organizational pride should focus on three concepts: identification, distributive justice and work conditions. The first can be addressed by promoting the values defended by the organization, giving the employees the opportunity to participate in initiatives that support those values, and stimulating social responsibility (De Roeck et al. 2016; Doh et al. 2011; Farooq and Salam 2020; Raza et al. 2021). Distributive justice is highly related with employees' perception of the possibility of being rewarded by a job well done and that these commendations are attributed based on merit. This can be achieved by not only leaving personal preferences aside when giving out promotions but also by celebrating small steps, using rewards to promote interest and recognize each employee's success in public (Katzenbach 2003; Lu and Roto 2016). Work conditions englobes a large set of conditions, from the quality of the physical work environment to job security or suitability of the attributed task. It is important that organizations understand that they not only need to promote healthy environments and all the necessary tools to employees, but also make sure the tasks given are adequate to their capabilities, stimulat- 
ing and in line with their career aspirations (Arnett et al. 2002; Welander et al. 2017). The relationship developed with management, even if only indirectly can also promote feelings of organizational pride. Therefore, management should be involved in daily activities, promoting cooperation between teammates and being available to answer doubts that may arise (Lu and Roto 2016).

\section{Conclusions}

The present study was able to determine the basis of organizational pride for the collected sample. Identification, distributive justice and work conditions were identified as the key promoters of organizational pride in a management consulting firm. This paper's contribution focuses on the drivers of organizational pride instead of looking at it as a mediator to enhance the organization performance and results as most authors do. Furthermore, it includes affective commitment in the model which allowed one to distinguish between causes of commitment through affective commitment and through organizational pride.

Additionally, some strategies to develop these focal concepts were defined in order to help organizations achieve their full potential. Managers should promote initiatives to celebrate the heritage and values of the organization, fostering organizational identification. Likewise, they should maintain clear goals and feedback processes, in order to obtain clear and accessible rewarding systems. Even though close relationships with direct management is not the main cause of organizational pride, it can also help foster this feeling. More important than that is to provide a proper work environment and keep employees invested in their tasks. Finally, promoting the organization's values and allowing employees to share them through initiatives and activities can enhance the feeling of belonging needed to promote organizational pride.

The technique used in this work allowed a comprehensive analysis of the drivers of organizational pride. It included different aspects of the organization which distinguishes this study from others, that mostly evaluate the effects of one particular aspect on organizational pride.

\section{Limitations and Future Research}

Even though it was possible to identify the main promoters of organizational pride, the sample used was considerably small. Moreover, it portrayed only a management consulting context which was not yet carried out, making it impossible to compare this study's results with other in similar contexts. Different industries may have distinct environments which will lead to different processes of creating organizational pride. Furthermore, the current model was not tested regarding the existence of significant endogeneity problems. The present analysis aimed to be a first approach to reveal the underlying constructs of organizational pride, more than identifying the dimension of the effects of the concepts already accepted as mediators, which is why further analysis was postponed to a second stage of research.

The literature has focused mostly on the isolated impact of one aspect in organizational pride, and most studies only consider one type of industry. There is a need for more global studies where the relationships between all aspects can be considered. Furthermore, future research should try to englobe different industries in order to look at organizational pride from a broader scope. It would be interesting to see if employees from different industries perceive and build organizational pride differently as this study suggested, regarding the importance given by the pharmaceuticals to work-life balance (Mas-Machuca et al. 2016).

Author Contributions: Conceptualization, V.P.; methodology, M.S.; validation, L.P., Á.D. and R.L.d.C.; formal analysis, L.P. and Á.D. investigation, L.P.; resources, V.P.; data curation, M.S. and Á.D.; writing—original draft preparation, M.S.; writing—review and editing, L.P.; visualization, M.S.; supervision, N.A.; project administration, N.A.; funding acquisition, L.P. All authors have read and agreed to the published version of the manuscript. 
Funding: This research received no external funding.

Data Availability Statement: All data were anonymized.

Conflicts of Interest: The authors declare no conflict of interest.

\section{References}

Allen, Natalie J., and John P. Meyes. 1990. The measurement and antecendents of affective, continuance and normative commitment to the organization. Journal of Occupational Psychology 63: 1-18. [CrossRef]

Ambrose, Maureen, and Marshall Schminke. 2009. The Role of Overall Justice Judgments in Organizational Justice Research: A Test of Mediation. Journal of Applied Psychology 94: 491-500. [CrossRef] [PubMed]

Arnett, Dennis B., Debra A. Laverie, and Charlie McLane. 2002. Using job satisfaction and pride as internal-marketing tools. Cornell Hotel and Restaurant Administration Quarterly 43: 87-96. [CrossRef]

Arredondo Trapero, Florina Guadalupe, Lida Esperanza Villa Castaño, José Carlos Vázquez Parra, and Jorge De La Garza García. 2017. Differences on self-perception of organizational pride and loyalty in millennial \& generation X, considering gender and seniority variables. Business and Economic Horizons 13: 270-86. [CrossRef]

Arshad, Ayesha, and Asma Imran. 2016. Impact of Organizational Morality on Employee Creativity: Mediating Role of Organizational Pride. International Review of Management and Business Research 5: 961-71.

Benitez, Jose, Jorg Henseler, Ana Castillo, and Florian Schuberth. 2020. How to perform and report an impactful analysis using partial least squares: Guidelines for confirmatory and explanatory IS research. Information and Management 57: 103168. [CrossRef]

Boezeman, Edwin J., and Naomi Ellemers. 2014. Volunteer leadership: The role of pride and respect in organizational identification and leadership satisfaction. Leadership 10: 160-73. [CrossRef]

Brosi, Prisca, Matthias Spörrle, and Isabell M. Welpe. 2018. Do we work hard or are we just great? The effects of organizational pride due to effort and ability on proactive behavior. Business Research 11: 357-73. [CrossRef]

Buchanan, Bruce. 1974. Building Organizational Commitment: The Socialization of Managers in Work Organizations. Administrative Science Quarterly 19: 533. [CrossRef]

Butler, Timothy David, Craig Armstrong, Alex Ellinger, and George Franke. 2016. Employer trustworthiness, worker pride, and camaraderie as a source of competitive advantage: Evidence from great places to work. Journal of Strategy and Management 9: 322-43. [CrossRef]

Cable, Daniel M., and Daniel B. Turban. 2003. The Value of Organizational Reputation in the Recruitment Context: A Brand-Equity Perspective. Journal of Applied Social Psychology 33: 2244-66. [CrossRef]

De Roeck, Kenneth, Aassâad El Akremi, and Valérie Swaen. 2016. Consistency Matters! How and When Does Corporate Social Responsibility Affect Employees' Organizational Identification? Journal of Management Studies 53: 1141-68. [CrossRef]

Doh, Johnathan P., Richard R. Smith, Stephen A. Stumpf, and Walter G. Tymon. 2011. Pride and professionals: Retaining talent in emerging economies. Journal of Business Strategy 32: 35-42. [CrossRef]

Durrah, Omar, Monica Chaudhary, and Moaz Gharib. 2019. Organizational cynicism and its impact on organizational pride in industrial organizations. International Journal of Environmental Research and Public Health 16: 1203. [CrossRef]

Ellemers, Naomi, Lotte Kingma, Jorgen van de Burgth, and Manuela Barreto. 2011. Corporate Social Responsibility As a Source of Organizational Morality, Employee. Journal of ORganizational Moral Psychology 1: 97-124.

Farooq, Muhammad Shoaib, and Maimoona Salam. 2020. Nexus between CSR and DSIW: A PLS-SEM Approach. International Journal of Hospitality Management 86. [CrossRef]

Fiernaningsih, Nilawati, Umar Nimran, Kusdi Raharjo, and Zainul Arifin. 2019. The role of work-life balance, organizational pride, and job satisfaction on organizational citizenship behaviour: Case study on hospitality employees in Indonesia. International Journal of Innovation, Creativity and Change 8: 73-94.

Gefen, David, Edward E. Rigdon, and Detmar Straub. 2011. An update and extension to SEM guidelines for administrative and social science research. MIS Quarterly: Management Information Systems 35. [CrossRef]

Gouthier, Matthias H. J., and Miriam Rhein. 2011. Organizational pride and its positive effects on employee behavior. Journal of Service Management 22: 633-49. [CrossRef]

Hair, Joseph F., G. Tomas M. Hult, Cristian M. Ringle, and Marko Sarstedt. 2016. A Primer on Partial Least Squares Structural Equation Modeling (PLS-SEM). Thousand Oaks: SAGE Publications Inc.

Hameed, Zahid, Ikram Ullah Khan, Tahir Islam, Zaryab Sheikh, and Safeer Ullah Khan. 2019. Corporate social responsibility and employee pro-environmental behaviors: The role of perceived organizational support and organizational pride. South Asian Journal of Business Studies 8: 246-65. [CrossRef]

Helm, Sabrina. 2013. A Matter of Reputation and Pride: Associations between Perceived External Reputation, Pride in Membership, Job Satisfaction and Turnover Intentions. British Journal of Management 24: 542-56. [CrossRef]

Holtom, Brooks C., Terence R. Mitchell, Thomas W. Lee, and Marion B. Eberly. 2008. Turnover and Retention Research: A Glance at the Past, a Closer Review of the Present, and a Venture into the Future. The Academy of Management Annals 2: 231-74. [CrossRef]

Holtom, Brooks, Kohyar Kiazad, and Yasaswini Dandu. 2019. Organizational practices that promote job embeddedness and retention. Organizational Dynamics 100731. [CrossRef] 
Kashif, Muhammad, Anna Zarkada, and Ramayah Thurasamy. 2017. Customer aggression and organizational turnover among service employees: The moderating role of distributive justice and organizational pride. Personnel Review 46: 1672-88. [CrossRef]

Katzenbach, Jon. 2003. Pride: A strategic asset. Strategy E Leadership 31: 34-38. [CrossRef]

Kraemer, Tobias, Welf H. Weiger, Matthias H. J. Gouthier, and Maik Hammerschmidt. 2020. Toward a theory of spirals: The dynamic relationship between organizational pride and customer-oriented behavior. Journal of the Academy of Marketing Science 48: 1095-115. [CrossRef]

Lehtman, Mark J., and Virgil Zeigler-Hill. 2020. Narcissism and job commitment: The mediating role of job-related attitudes. Personality and Individual Differences 157. [CrossRef]

Lu, Yichen, and Virpi Roto. 2016. Design for Pride in the Workplace. Psychology of Well-Being 6. [CrossRef]

Mas-Machuca, Marta, Jasmina Berbegal-Mirabent, and Ines Alegre. 2016. Work-life balance and its relationship with organizational pride and job satisfaction. Journal of Managerial Psychology 31: 586-602. [CrossRef]

Masterson, Courtney, Robert C. Liden, and Donald Kluemper. 2017. Pelling back the layers: A multi-methdo investigation of organizational pride. Academy of Management Annual Meeting Procedings 1. [CrossRef]

Muzakki, Praptini Yulianti. 2020. Building Organizational Pride through Corporate Social Responsibility. International Journal of Psychosocial Rehabilitation 24: 728-34. Available online: https:/ /www.psychosocial.com/article/PR270065/14045/ (accessed on 16 March 2021).

Nakamura, Jeanne. 2013. Pride and the experience of meaning in daily life. Journal of Positive Psychology 8: 555-67. [CrossRef]

Ng, Thomas W. H., Kai Chi Yam, and Herman Aguinis. 2019. Employee perceptions of corporate social responsibility: Effects on pride, embeddedness, and turnover. Personnel Psychology 72: 107-37. [CrossRef]

Raza, Ali, Muhammad Farrukh, Muhammad Khalid Iqbal, Muhammad Farhan, and Yihua Wu. 2021. Corporate social responsibility and employees' voluntary pro-environmental behavior: The role of organizational pride and employee engagement. Corporate Social Responsibility and Environmental Management, August 2020: 1-13. [CrossRef]

Schaufeli, Wilmar B., Arnold B. Bakker, and Marisa Salanova. 2006. The measurement of work engagement with a short questionnaire: A cross-national study. Educational and Psychological Measurement 66: 701-16. [CrossRef]

Seyedpour, Seyed Mostafa, Ali Safari, and Ali Nasr Isfahani. 2020. Formulating an organizational pride model for the National Iranian Oil Company. Cogent Business and Management 7. [CrossRef]

Tracy, Jessica L., and Richard W. Robins. 2007. The psychological structure of pride: A tale of two facets. Journal of Personality and Social Psychology 92: 506-25. [CrossRef] [PubMed]

Welander, Jonas, Juliska Wallin, and Kerstin Isaksson. 2017. Job Resources to Promote Feelings of Pride in the Organization: The Role of Social Identification. Scandinavian Journal of Work and Organizational Psychology 2: 7. [CrossRef]

Widyanti, Rahmi, Gusti Irhamni, Silvia Ratna, and Basuki. 2020. Organizational Justice and Organizational Pride to achieve job satisfaction and Job performance. Journal of Southwest Jiaotong University 55. [CrossRef] 